\title{
Metal bioaccumulation and metallothionein concentrations in larvae of Crassostrea gigas
}

\section{Gautier Damiens $^{\mathrm{a}}$, Catherine Mouneyrac ${ }^{\mathrm{b}}$, Françoise Quiniouc ${ }^{\mathrm{c}}$, Edouard His ${ }^{\mathrm{c}}$, Mauricette Gnassia-Barelli ${ }^{\mathrm{a}}$ and Michèle Roméo ${ }^{\mathrm{a}^{*}}$}

\author{
aUMR 1112 INRA-UNSA R.O.S.E., Faculty of Sciences, Parc Valrose, B.P. 71, 06108 Nice Cedex 2, France \\ ${ }^{b}$ Centre d'Etude et de Recherche sur les écosystèmes aquatiques (CEREA), IBEA/UCO, 3 Place André Leroy, \\ B.P. 10808, 49008 Angers Cedex 01, France and Service d'Ecotoxicologie, SMAB-ISOMER, Faculté des \\ Sciences, 2 rue de la Houssinière, BP 92208, 44322 Nantes Cedex 3, France \\ 'Département Biogéochimie et Ecotoxicologie IFREMER—Centre de Brest, B.P. 70, 29280 Plouzane, France \\ *: Corresponding author : Tel.: +33 49207 6822; fax: +33 49207 6563. romeo@unice.fr
}

\begin{abstract}
Larval stages of bivalve molluscs are highly sensitive to pollutants. Oysters from a hatchery from Normandy (English Channel) were induced to spawn, and fertilized eggs were exposed to copper or cadmium for $24 \mathrm{~h}$. Metal accumulation (from 0.125 to $5 \mu \mathrm{g} \mathrm{Cu} \mathrm{L-1}$ and from 25 to $200 \mu \mathrm{g} \mathrm{Cd} \mathrm{L-1)}$ and MT concentrations were measured in larvae. Compared to controls, larvae accumulated copper and cadmium with an increase in MT concentrations particularly with cadmium (i.e. $130.96 \mathrm{ng} \mathrm{Cu}$ (mg protein) -1 and $12.69 \mu \mathrm{g} \mathrm{MT}$ (mg protein)-1 at $1 \mu \mathrm{g} \mathrm{Cu} \mathrm{L-1}$ versus $23.19 \mathrm{ng} \mathrm{Cu}$ (mg protein)-1 and $8.92 \mu \mathrm{g}$ MT (mg protein)-1 in control larvae; $334.3 \mathrm{ng} \mathrm{Cd}$ (mg protein)-1 and $11.70 \mu \mathrm{g}$ MT (mg protein)-1 at $200 \mu \mathrm{g} \mathrm{Cd} \mathrm{L-1}$ versus $0.87 \mathrm{ng} \mathrm{Cd}$ (mg protein)-1 and $4.60 \mu \mathrm{g}$ MT (mg protein)-1 in control larvae). Larvae were also obtained from oysters of a clean area (Arcachon Bay) and a polluted zone (Bidassoa estuary) and exposed to copper in the laboratory, their MT concentration was measured as well as biomarkers of oxidative stress. Biomarker responses and sensitivity to copper for the larvae from Arcachon oysters were higher than for those from Bidassoa.
\end{abstract}

Keywords: Crassostrea gigas larvae; Cadmium; Copper; Metallothionein; Arcachon Bay; Bidassoa estuary 


\section{1 - Introduction}

Early embryo-larval stages of bivalve molluscs have been shown to be highly sensitive to micropollutants. particularly to metals (Calabrese et al., 1977; Martin et al., 1981; Pavičić, 1981; Beiras and His, 1995). One of the best methods for assessing the bioavailability of contaminants is to observe their accumulation in organisms. Recent studies demonstrated the ability of bivalve larvae to bioaccumulate metals (Geffard et al., 2002; Geffard et al., 2003). Metallothionein has been shown to be a potential biomarker for metal contamination in aquatic environment. The use of bivalve metallothionein has been reviewed (Langston et al., 1998; Cosson, 2000). MTs are low-molecular weight, cysteine rich, inducible proteins that function in metal homeostasis and detoxification (Hamer, 1986; Engel and Brouwer, 1989). MTs are cytosolic proteins. The presence of cysteine in MTs confers substantial metal binding capabilities. The importance of MTs in ameliorating metal toxicity in bivalves has been demonstrated (Viarengo et al., 1987; Roesijadi, 1992). Some studies have dealt with metallothionein induction in embryo-larval stages of molluscs (Pavičić et al., 1985; Pavičić et al., 1994; Roesijadi et al., 1995, Geffard, 2001).

In the present study, fertilized Crassostrea gigas eggs were exposed to copper or cadmium for $24 \mathrm{~h}$, period required to complete embryogenesis (obtention of D-shaped larvae). The bioaccumulation of metals and MT concentrations were measured in each experimental series at the end of each exposure period. As abiotic factors are likely to interfere with MT synthesis in aquatic animals (Cosson, 2000), the effect of temperature and salinity were studied in control larvae before beginning the metal exposure experiments.

Besides, since organisms from polluted areas, especially metal-rich estuaries (i.e. Restronguet Creek in England, Gironde estuary in France) can react to metal exposure differently from animals leaving in pristine areas, the origin of larvae was taken into consideration. This origin considered as "environmental history" by De Kock and Kramer (1994) may be a cause of variation in MT induction. The state of adaptation (studied as MT concentrations) of local populations to copper concentrations was tested on larvae from oysters living in a clean area (Arcachon, SW of France, Atlantic Ocean) and from a heavy copper-polluted area (Bidassoa estuary, boarder between France and Spain, Atlantic Ocean). The hypothesis was that fertilized eggs from adult oysters from Bidassoa, which have been living all their life in a contaminated estuary, were more able to stand the toxic effects of copper than those from the Arcachon Basin.

\section{Materials and Methods}

\subsection{Obtaining larvae}

Mature oysters (Crassostrea gigas) were conditoned in a hatchery or collected during the natural reproduction period (this last experiment described in section 2.6.). Oysters from hatcheries are considered as "clean" since they are consumed, the safety of food to the consumer being a major concern of oyster producers (Bragigand et al., 2004). In the laboratory, oysters were then induced to spawn by thermal stimulation (His et al. 1997, 1999, Quiniou et al., 2005). Females in the laying process were isolated in $1 \mathrm{l}$ of filtered $(0.22 \mu \mathrm{m})$ reference sea water (Quiniou et al., 2005) while spawning males were put in $500 \mathrm{ml}$ of filtered reference sea water, to obtain a sperm-dense suspension. The oocytes and sperm of different oysters were observed after sieving through $100 \mu \mathrm{m}$ for oocytes and $32 \mu \mathrm{m}$ for spermatozoa under an inverted microscope, and the most reproductive pair (regular oocytes and very 
mobile spermatozoa) was selected for the experiment. The oocytes were fertilized by the sperm-dense suspension (until 10 spermatozoa for 1 oocyte). Fifteen minutes after fertilization, embryos were counted and placed into $2 \mathrm{l}$ beakers (60,000 fertilized eggs per liter) filled with $0.2 \mu \mathrm{m}$ reference filtered sea water (two replicates per condition and 6 beakers per replicate, one replicate therefore constitutes one pool of ca 720,000 larvae). After incubation, the larvae were recovered through a sieve $(32 \mu \mathrm{m})$, freeze-dried and stored for analysis.

Fertilized eggs from one female and one male were used to minimize genetic variability as recommended by Stebbing et al. (1980). In some cases (effect of temperature and salinity and first experiment with larvae from Arcachon and Bidassoa), two couples were used to produce larvae.

\subsection{Effect of temperature and salinity}

Two temperatures $\left(20^{\circ} \mathrm{C}\right.$ and $\left.25^{\circ} \mathrm{C}\right)$ and three salinities $(25,30$ and 35) for each temperature were used. In the field, the natural spawning occurs from $19{ }^{\circ} \mathrm{C}$ and the optimal D-larvae development in the laboratory is reached at $25^{\circ} \mathrm{C}$. The chosen salinities were those found along the French Atlantic coast where oysters are cultivated. Embryos were incubated at the chosen temperature and salinity for $24 \mathrm{~h}$ in the dark until D-larvae were obtained (His et al., 1997). After incubation larvae were recovered through a sieve $(32 \mu \mathrm{m})$ and treated as described in section 2.4. After salinity and temperature experiment, an average salinity (30.0 $\pm 0.5)$ and an average temperature $\left(23 \pm 1^{\circ} \mathrm{C}\right)$ were chosen for the subsequent experiments.

\subsection{Effect of metals}

Three experiments were conducted to study the effect of each metal (copper or cadmium introduced into the medium as chloride salts) on the metal uptake and the concentration of MTs. The experiments (experiments I, II and III for each metal) were classed according to the date of the obtention of larvae. The contamination concentrations were below the toxicity thresholds (Robert and His, 1985; Damiens et al., 2004; Quiniou et al., 2005). The chosen concentrations were low for copper which was introduced into the experimental medium at concentrations ranging from 0.25 to $5 \mu \mathrm{g} \mathrm{Cu} \mathrm{l}^{-1}$ since Damiens et al. (2004) estimated the physiological status of the larvae by evaluating $\mathrm{CuSO}_{4}$ concentration producing $50 \%$ of abnormal larvae ; the toxic concentration (EC50) ranged between 24 and $47.8 \mu g \mathrm{CuSO}_{4} \mathrm{l}^{-1}$ i.e. ca 5.8 to $12 \mu \mathrm{g} \mathrm{Cu} \mathrm{l}^{-1}$, in natural seawater. Robert and His (1985) reported EC50 values higher than $50 \mu$ g cadmium $\mathrm{l}^{-1}$ for $C$. gigas larvae, i.e. cadmium toxicity to bivalve larvae was much lower than that of copper. It is why cadmium was used, in this study, at high concentrations (50, 100 and $200 \mathrm{\mu g} \mathrm{l}^{-1}$ ) to find a significant uptake and higher MT concentrations in exposed larvae compared to the controls.

\subsection{MT analysis}

The determination of MT concentrations in larvae required partial purification which was performed according to the method of Thompson and Cosson (1984) that was modified. Each replicate of larvae was homogenized using a Potter-Kontes glass homogenizer fitted with a teflon pestle in a Tris- $\mathrm{NaCl}$ buffer solution (0.02 M, pH 8.6), with a ratio of $5 \mathrm{ml}$ buffer per $\mathrm{g}$ of larvae (wet weight). Oxidation of MT molecules was avoided by working at $4{ }^{\circ} \mathrm{C}$ with $\beta$ mercaptoethanol solution $(10 \mathrm{mM})$ added to the TRIS buffer. The homogenate was then centrifuged at $9,000 \mathrm{~g}\left(4^{\circ} \mathrm{C}\right)$ to obtain the post-mitochondrial fraction (S9) where metal 
concentration was measured. S9 was centrifuged $\left(25,000 \mathrm{~g}, 55 \mathrm{~min}\right.$ at $\left.4{ }^{\circ} \mathrm{C}\right)$. MT was isolated from an aliquot of the supernatant, by a second centrifugation $\left(15000 \mathrm{~g}, 10 \mathrm{~min}\right.$ at $\left.4{ }^{\circ} \mathrm{C}\right)$ after heating for $15 \mathrm{~min}$ at $75^{\circ} \mathrm{C}$. This supernatant, containing the MT, was frozen at $-80{ }^{\circ} \mathrm{C}$ until analysis. The MT assay was performed by differential pulse polarography. A PAR Model 174 analyser, PAR/EG \& G Model 303 static mercury drop electrode (SMDE) and an X-Y recorder (RE 0089) were used. The concentration of thiol groups (SH) was determined using Brdickà reagent (Brdickà, 1933) according to the method described by Thompson and Cosson (1984). Three measurements were performed in each sample. The concentrations of MTs are expressed as $\mu \mathrm{g}$ MT mg protein ${ }^{-1}$ and as $\mu \mathrm{g} \mathrm{MT} \mathrm{g^{-1 }}$ wet weight. Total proteins were determined according to Bradford (1976). This last determination is considered as more precise than the wet weight of larvae due to difficulties in removing sea water from the sieve during collection. Moreover, when considering biomarker measurements (see section 2.6), results are commonly presented as a function of protein concentration. When possible, both kinds of results were given.

\subsection{Metal analysis}

Copper and cadmium were determined in S9 fractions of larvae. These fractions were digested with nitric acid (65\%, Merck Suprapur) in a microwave oven (CEM MDS 81 D). Analyses were carried out on the resulting solutions by flameless atomic absorption spectrophotometry (GBC 904 AA). Deuterium background correction was used. The analytical procedure was calibrated against a standard reference material, namely lobster hepato-pancreas (TORT-2 provided by the National Research Council of Canada). Results of these analyses are given in Table 1 . The results are in agreement with the certified values. Metal determinations in the medium were carried out by anodic stripping voltametry.

Table 1. Analysis of the reference material Lobster Hepatopancreas TORT-2. (National Research Council Canada). Mean values \pm 1 standard deviation.

\begin{tabular}{lccc}
\hline Metal & $\begin{array}{c}\text { Certified values }\left(\mu \mathrm{g} \mathrm{g}^{-1} \mathrm{dry} \mathrm{wt}\right) \\
\text { Mean } \pm 1 \text { S.D. }\end{array}$ & $n$ & Recorded values \\
\hline $\mathrm{Cd}$ & $26.7 \pm 0.6$ & 5 & $27.0 \pm 0.7$ \\
$\mathrm{Cu}$ & $106 \pm 10$ & 5 & $101 \pm 1$ \\
\hline
\end{tabular}

\subsection{Effect of the origin of larvae on MT concentrations}

Pacific oysters were collected during the natural spawning from two different locations : the Arcachon Basin and the Bidassoa estuary. The tolerance of larvae to copper was compared according to their origin. As mentioned above, larvae were incubated in increasing concentrations of $\mathrm{CuSO}_{4}\left(0,20,40,60,80 \mu \mathrm{guSO}_{4} \mathrm{l}^{-1}\right)$ to determine the percentage of abnormal larvae at each concentration (3 replicates per concentration).

Larvae (produced by two couples of parents) from both origins and the contaminant $\left(\mathrm{CuCl}_{2}\right)$ were put in contact during $24 \mathrm{~h}$. The salinity was kept at $30.0 \pm 0.5$ and the temperature at $23 \pm 1{ }^{\circ} \mathrm{C}$. The first experiment occurred in July 2003 with concentrations of 0.125, 0.5, 1.25 and $5 \mu \mathrm{g} \mathrm{Cu}{ }^{-1}$ and the second in July 2004, the copper concentrations for the second experiment $\left(0.25,0.5\right.$ and $\left.1 \mu \mathrm{g} \mathrm{Cu} \mathrm{l}^{-1}\right)$ were chosen according to the results of the first experiment. MT concentrations were determined as above-mentioned.

In July 2004, the experiment was carried out with larvae from one couple of parents, the larvae were very abundant : six 2-l incubation beakers (one pool) were used for MT 
determinations and six 2-l incubation beakers (three pools) could be dedicated to biomarker determination. Copper concentrations was measured in S9 fractions from the larvae and two biomarkers of oxidative stress (Cossu et al., 1997) : the catalase activity and the concentration of TBARS (Thio-Barbituric Acid Reactive Substances) were also measured according to the methods described in Damiens et al. (2004).

\subsection{Statistics}

All chemical and biochemical determinations were performed in two replicates (one pool of larvae) by condition and no statistics could be performed. When two couples of adult larvae were used, more determinations were carried out on two or more pools, data were then tested for homogeneity of variance and for normal distribution and ANOVA was calculated, post-hoc comparison was done using Tukey’s tests (JPM IN 5.1 software).

\section{Results}

Effect of temperature and salinity on MT concentrations in control C. gigas larvae

The results are expressed as $\mu \mathrm{g}$ MT per g of weight wet (protein concentrations could not be determined). Salinity has no influence on MT concentrations measured in the larvae whereas temperature significantly increases the concentrations of MTs (Fig. 1, larvae from october 2003). At all salinities, MT concentrations are higher with a mean value of $252.5 \pm$ $20.7 \mu \mathrm{g} \mathrm{MT} \mathrm{g}{ }^{-1}$ at $25^{\circ} \mathrm{C}$ compared to $178.7 \pm 18.9 \mu \mathrm{g} \mathrm{MT} \mathrm{g}^{-1}$ at $20^{\circ} \mathrm{C}$ (Tukey’s test significant at $\mathrm{p}<0.05)$.

Fig. 1. Variation of MT concentrations in control larvae (expressed as $\mu \mathrm{g} \mathrm{MT} \mathrm{g}^{-1}$ wet weight) as function of temperature (20 and $25^{\circ} \mathrm{C}$ ) and salinity (indicated on $\mathrm{X}$ axis : 25, 30 and 35)

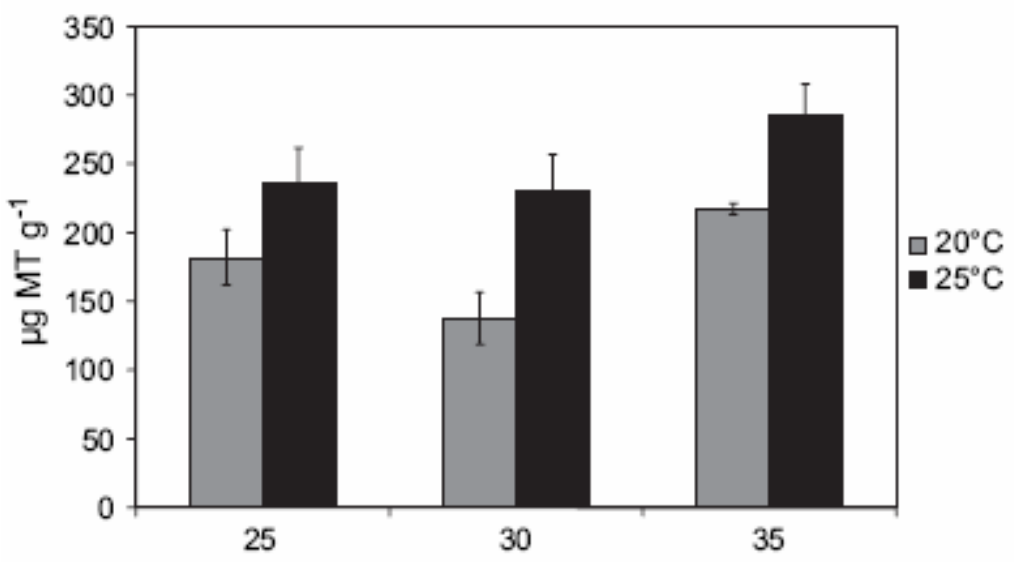




\section{Effect of copper exposure on C. gigas larvae}

The results are shown in Table 2. There are few differences between nominal and measured concentrations of dissolved metal. The concentration of dissolved copper in the medium after $24 \mathrm{~h}$ exposure demonstrates that copper was not lost by adsorption on the vessel during the experiment. Protein concentrations in larvae increase as a function of season (with the spawning period of adult oyster which starts in May) from 4.17 to $9.04 \mathrm{mg} \mathrm{ml}^{-1}$. Compared to the controls, copper is not accumulated in experiment I (mid-February), MT concentration did not change in exposed larvae. At $1 \mu \mathrm{g} \mathrm{Cu} l^{-1}$ (experiment II, beginning of May) an increase in copper uptake is found which does not correspond to an increase in MT concentration. Exposed larvae present high copper content and MT concentrations in experiment III (end of May) compared to the controls. Copper exposure provokes low MT induction (as discussed below).

\section{Effect of cadmium exposure in C. gigas larvae}

Results are shown in Table 3. Here again, there are few differences between nominal and measured concentrations of dissolved metal. As for copper, protein concentrations in larvae increase as a function of season, a high concentration of proteins is found end of March. In experiment I (beginning of March), there was a problem with the incubator temperature which failed from $23^{\circ} \mathrm{C}$ to $16^{\circ} \mathrm{C}$ and a dramatic decrease of MT concentration in cadmium-exposed larvae compared to the controls was observed. For experiments II (end of March) and III (end of April), a strong cadmium uptake was noted in exposed larvae compared to the controls. There was an increase (ca two-fold) in MT concentrations of larvae exposed at $200 \mu \mathrm{g} \mathrm{Cd} \mathrm{^{-1 }}$ compared to the controls.

Table 2 : Copper (ng Cu mg protein ${ }^{-1}$ ) and metallothionein ( $\mu$ g MT mg protein ${ }^{-1}$ ) concentrations in Crassostrea

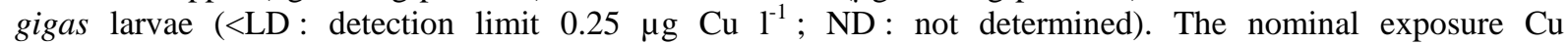
concentration and the measured $\mathrm{Cu}$ concentration in the incubation medium are also given.

\begin{tabular}{cccccc}
\hline Experiment & Exposure & $\begin{array}{c}\mathrm{Cu} \\
\mu \mathrm{g} \mathrm{l}^{-1}\end{array}$ & $\begin{array}{c}\text { Proteins } \\
\mathrm{mg} \mathrm{ml}^{-1}\end{array}$ & $\begin{array}{c}\mathrm{ng} \mathrm{Cu} \\
\mathrm{mg} \mathrm{prot.}^{-1}\end{array}$ & $\begin{array}{c}\mu \mathrm{g} \mathrm{MT} \\
\text { mg prot. }^{-1}\end{array}$ \\
\hline $\begin{array}{c}\text { Exp. I } \\
\text { February }\end{array}$ & Control & $\mathrm{ND}$ & 4.17 & 20.08 & 11.75 \\
& 0.25 & $\mathrm{ND}$ & 4.34 & 23.24 & 8.29 \\
& 0.50 & $\mathrm{ND}$ & 3.62 & 20.54 & 13.20 \\
\hline $\begin{array}{c}\text { Exp.II } \\
\text { Mainning of }\end{array}$ & Control & $<\mathrm{L.D}$. & 8.42 & 26.43 & 9.83 \\
& 0.50 & 0.48 & 6.49 & 29.59 & 10.35 \\
\hline $\begin{array}{c}\text { Exp. III } \\
\text { End of May }\end{array}$ & Control & $\mathrm{ND}$ & 9.04 & 23.19 & 10.23 \\
& 0.50 & $\mathrm{ND}$ & 7.85 & 55.41 & 14.62 \\
& 1.00 & $\mathrm{ND}$ & 5.18 & 130.96 & 12.69 \\
\hline
\end{tabular}


The tolerance of larvae from Arcachon and Bidassoa is given in Fig. 2 a (Arcachon) and Fig. 2 b (Bidassoa). Larvae from Arcachon present an EC50 of $41.4 \mu g \mathrm{CuSO}_{4} \mathrm{l}^{-1}$ (i.e. $10.4 \mu \mathrm{g}$ $\mathrm{Cu} \mathrm{l}{ }^{-1}$ ) whereas EC50 reaches $71.7 \mu \mathrm{g} \mathrm{CuSO}_{4} l^{-1}$ (i.e. ca $18 \mu \mathrm{g} \mathrm{Cu} \mathrm{l}^{-1}$ ) in samples originating from Bidassoa ; $\mathrm{EC}_{50}$ was calculated using EPA Probit analysis program (version 1.5) or graphically. This demonstrates the greatest tolerance of Bidassoa larvae compared to those of Arcachon.

The results (in duplicate) of the first experiment, carried out in July 2003, are shown in Fig 3. A two-way ANOVA (origin and effect of contamination) performed on protein concentrations is significant ( $p<0.0001$ ), the protein concentrations are higher in the larvae from Bidassoa $\left(2.92 \pm 0.37 \mathrm{mg} \mathrm{ml}^{-1}\right)$ than in those from Arcachon $\left(1.77 \pm 0.43 \mathrm{mg} \mathrm{ml}^{-1}\right)$. No effect of copper on protein concentrations is noted. Another two-way ANOVA performed on MT concentrations is significant $(\mathrm{p}<0.0001)$. There is an effect of the origin of larvae $(\mathrm{p}=$ $0.001)$ and an effect of copper $(p<0.005)$. The interaction origin $x$ contamination is significant $(\mathrm{p}<0.005)$. When considering larvae from Arcachon oysters, the effect of copper significantly decreases MT concentrations (ANOVA significant at $\mathrm{p}<0.0005$, the levels of significance between control and exposed larvae are shown in Fig. 3) from $0.5 \mu \mathrm{g} \mathrm{Cu} \mathrm{l}^{-1}$ $\left(87.59 \pm 13.4 \mu \mathrm{g} \mathrm{MT} \mathrm{g}^{-1}\right.$ and $\left.9.65 \pm 1.44 \mu \mathrm{g} \mathrm{MT} \mathrm{mg} \mathrm{protein}^{-1}\right)$ to $5 \mu \mathrm{g} \mathrm{Cu} \mathrm{l}{ }^{-1}(65.90 \pm 13.51$ $\mu \mathrm{g} \mathrm{MT} \mathrm{g}{ }^{-1}$ and $6.37 \pm 1.07 \mu \mathrm{g}$ MT mg protein $\left.{ }^{-1}\right)$ compared to the controls $(124.38 \pm 22.65 \mu \mathrm{g}$ $\mathrm{MT} \mathrm{g}^{-1}$ and $12.75 \pm 2.37 \mu \mathrm{g}$ MT mg protein ${ }^{-1}$ ). In larvae from Bidassoa oysters, the decrease of MT concentrations as a function of copper added to the medium is not found (ANOVA non significant $\mathrm{p}=0.749 ; 68.7 \pm 13.0 \mu \mathrm{g} \mathrm{MT} \mathrm{g}^{-1}$ and $7.19 \pm 0.84 \mu \mathrm{g} \mathrm{MT} \mathrm{mg} \mathrm{protein}{ }^{-1}$ in larvae exposed to $5 \mu \mathrm{g} \mathrm{Cu}^{-1}$ versus 101.4 $\pm 19.1 \mu \mathrm{g} \mathrm{MT} \mathrm{g}{ }^{-1}$ and $7.74 \pm 1.56 \mu \mathrm{g}$ MT mg protein ${ }^{-1}$ in controls).

The results of the second experiment (July 2004) are presented in Table 4. A two-way ANOVA (origin and effect of contamination) performed on protein concentrations is significant $(p<0.0001)$. There is an effect of the origin of larvae $(p<0.0001)$ and no effect of copper on protein concentrations $(p=0.240)$. Copper accumulation could be measured in this experiment and results are expressed in ng $\mathrm{Cu}$ per mg of proteins or in $\mathrm{ng} \mathrm{Cu}$ per $\mathrm{g}$ of wet weight. Compared to the controls, copper concentrations in larvae from Arcachon oysters tend to increase between 0.25 and $0.5 \mu \mathrm{g} \mathrm{Cu} \mathrm{l} l^{-1}$ and sharply decrease at $1 \mu \mathrm{g} \mathrm{Cu} \mathrm{l}{ }^{-1}$. The same diminution is observed at $1 \mu \mathrm{g} \mathrm{Cu} \mathrm{l^{-1 }}$ in larvae from Bidassoa oysters. Copper induces higher MT concentrations in exposed larvae from each series (Arcachon or Bidassoa, Table 4) than in the controls. Biomarkers of oxidative stress : TBARS concentrations and catalase activity are also shown in Table 4. ANOVA performed for TBARS concentrations showed no significant differences in both series. Catalase activity is decreased from $0.25 \mu \mathrm{g} \mathrm{Cu} \mathrm{l} \mathrm{l}^{-1}$ in Arcachon samples (ANOVA significant at $\mathrm{p}<0.0005$ ) and at $1 \mu \mathrm{g} \mathrm{Cu}{ }^{-1}$ in Bidassoa samples (ANOVA significant at $\mathrm{p}<0.05$ ). 
Fig. 2. Percentage of abnormal larvae (Y axis) as a function of increasing concentrations of $\mathrm{CuSO}_{4}\left(0\right.$ to $80 \mu \mathrm{l}^{-}$ ${ }^{1}$ ) in the incubation medium of larvae : a) from Arcachon; b) from Bidassoa. The EC50 was determined by probit calculation given in the text and graphically.

a) Arcachon

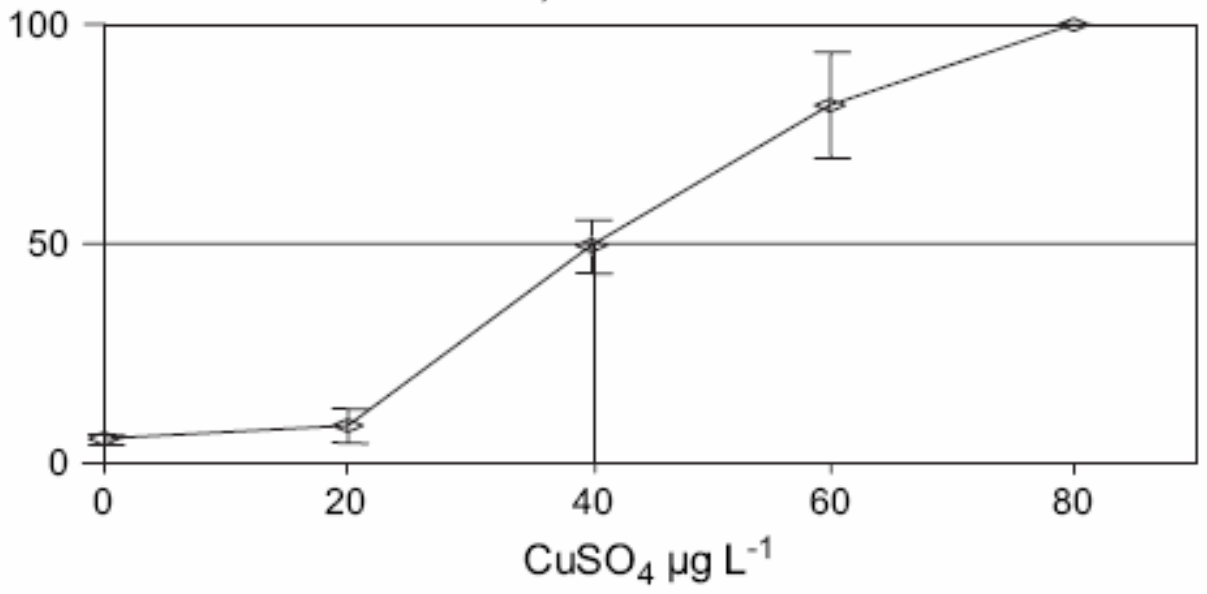

b) Bidassoa

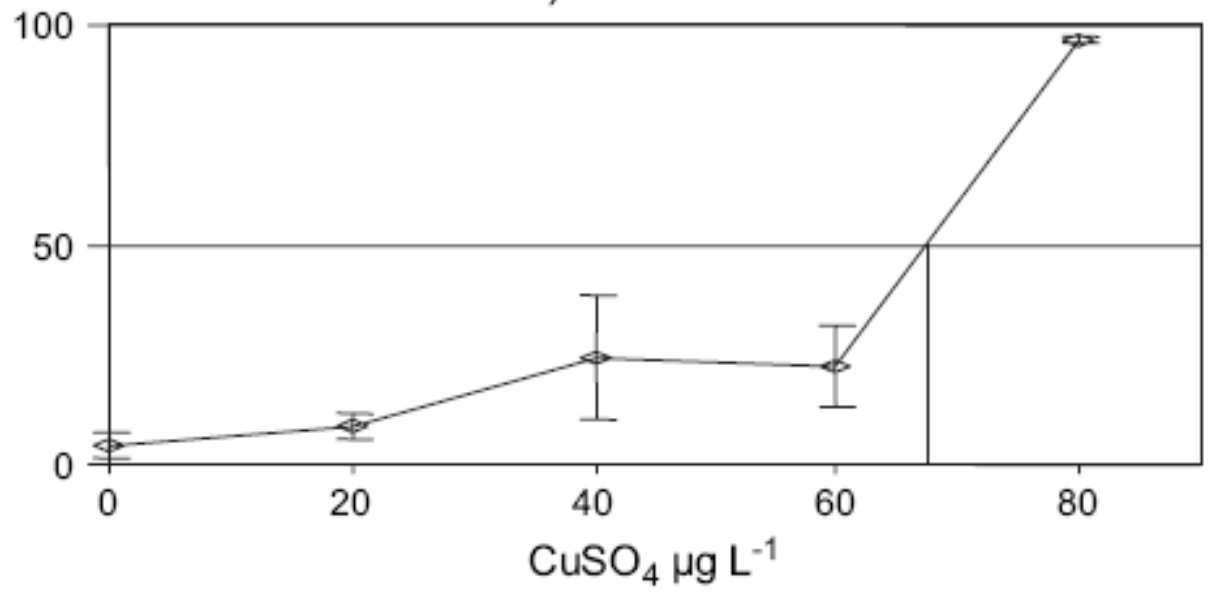


Fig. 3. MT concentrations ( $\mu \mathrm{g}$ MT $\mathrm{mg}$ protein $^{-1} \pm 1$ standard deviation) in larvae from parents from Arcachon ( $\square$ ) or Bidassoa ( $\square$ ) exposed to increasing copper concentrations in the experiment of July 2003. ANOVA significant, Tuckey’s test post-hoc comparison with the controls significant at ${ }^{*} \mathrm{p}<0.05$, ${ }^{* *} \mathrm{p}<0.01$.

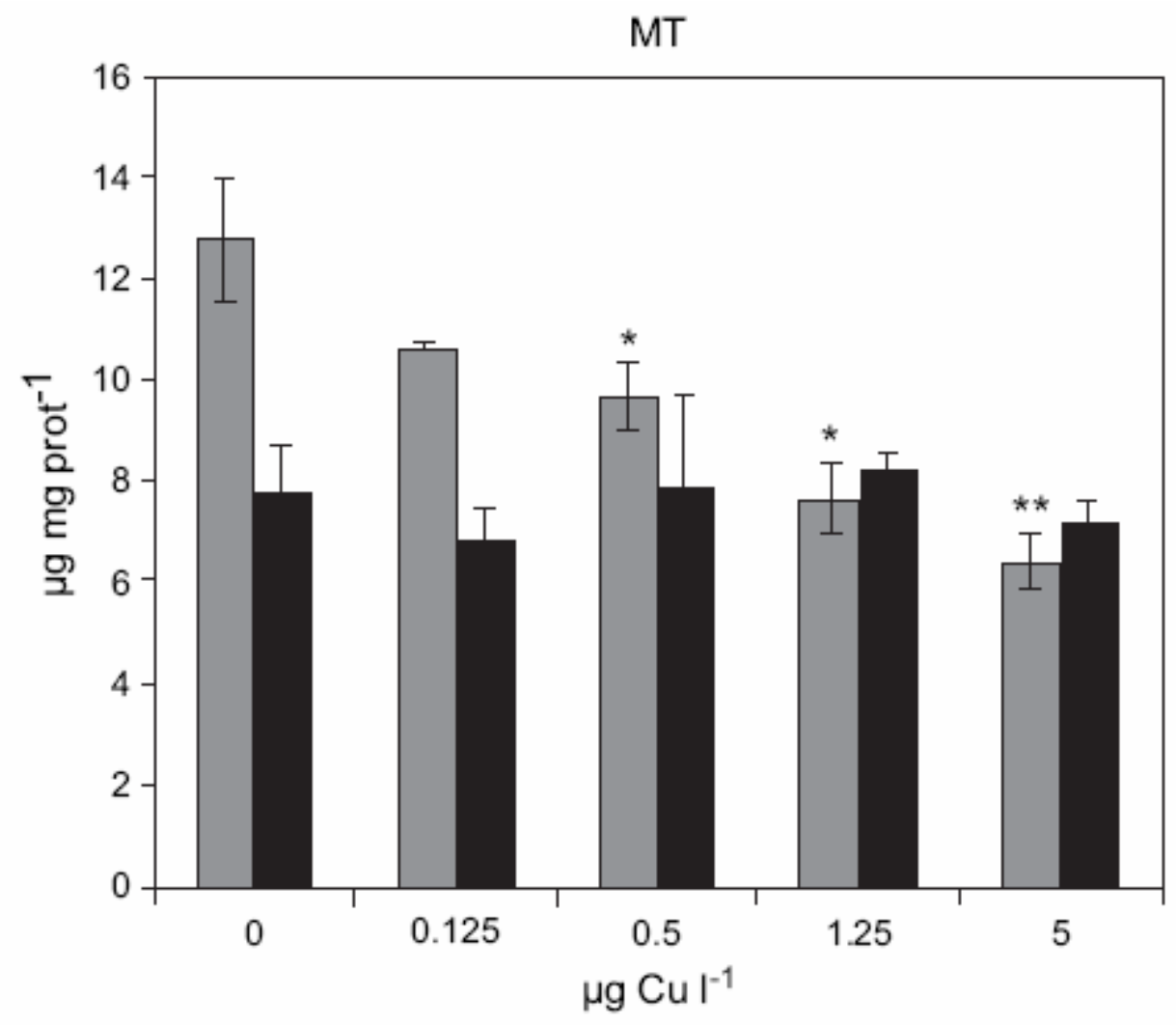

\section{Discussion}

The choice of oyster larvae was not done at random since the most reproductive pairs were selected in order to obtain the fittest individuals to perform our experiments. Nevertheless, larvae show different responses to abiotic parameters and pollutant exposure. The concentrations of metal exposure were explained in section 2.3.

\section{Effect of temperature and salinity}

The low effect of salinity on MT concentrations in oyster larvae (Fig. 1) was already noted in adult bivalves by Amiard-Triquet et al. (1998) in Arctic populations of Macoma balthica and Mytilus edulis whereas the influence of sexual status was significant. Moreover, Mouneyrac et al. (1998) did not put into evidence MT concentration variations in the oyster Crassostrea gigas along a salinity gradient in the Gironde estuary.

The effect of temperature found here (higher MT concentrations at higher temperature, Fig. 1 ) is also observed in bivalves by different authors. Season seems to influence greatly the synthesis of MTs in specific organs of adult bivalves (Cosson, 2000). Viarengo et al. (1997) showed a seasonal increase of metallothionein content in the digestive gland of wild adult mussels (Mytilus galloprovincialis) in relation with a higher metabolic activity during late spring and summer. This phenomenon may be compared with our findings although the 
fertilized eggs were obtained with oysters, collected at the end of summer when temperature reached $25^{\circ} \mathrm{C}$, these eggs were placed at 20 and $25^{\circ} \mathrm{C}$ until D-stage.

\section{Effect of metals on metal uptake and MT concentrations in C. gigas larvae}

The chosen copper concentrations are environmentally realistic since dissolved copper concentrations has been reaching ca $10 \mu \mathrm{g} \mathrm{Cu} \mathrm{l}^{-1}$ in French harbours since the banning of TBT. Generally, Schiff et al. (2004) established a mean dissolved copper emission of 20.5 to 33.6 g per month into pleasure boat harbours. Geffard (2001) estimated that the dissolved

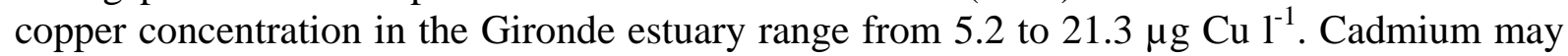
be present at high concentrations in some hot spots such as the Gironde estuary, where

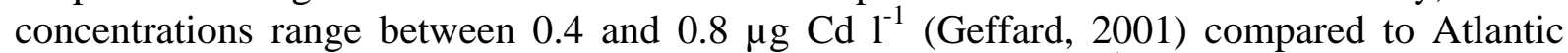
waters which show concentrations ranging from 0.2 to $12 \mathrm{ng} \mathrm{Cd} \mathrm{l}^{-1}$ (Cossa and Lassus, 1989). Table 2 demonstrates a strong seasonal effect : the copper uptake by larvae begins in May (experiment II) without increase in MT concentrations, then, at the end of May (experiment III) larvae significantly accumulate copper and subsequently provoke a relatively low MT induction from $0.5 \mu \mathrm{g} \mathrm{Cu} \mathrm{l}^{-1}$ (ca 1.6 fold by comparison with the controls).

The same seasonal effect is observed in the experiments conducted with cadmium (Table 3). In the beginning of March, the decrease of the incubator temperature provoked a low growth rate of larvae and low concentration of protein was found in both control and exposed larvae, a slight uptake of cadmium was observed associated with a low MT concentration in exposed larvae. At $100 \mu \mathrm{g} \mathrm{Cd} \mathrm{l}^{-1}$, cadmium appears to prevent both protein and MT induction. In the two subsequent experiments (experiments II and III), both cadmium uptake and increase of MT concentrations were observed suggesting the importance of this protein in the detoxification process.

Copper and cadmium are accumulated by larvae and provoked an increase in MT concentrations when the period of spawning of oysters in the laboratory is close to the "natural" spawning which starts in May. The protein concentration in larvae developing in the laboratory follows the sexual maturity of parents. Using the methods described in Boutet et al. (2002, 2003), Quiniou et al. (2004) observed a strong and significant induction in MT and HSP 70 in oyster larvae exposed to cadmium when the sexual maturity of parents was maximal whereas the induction was not significant when the maximal sexual maturity was not reached. This in agreement with our findings.

Pavičić et al. (1985) found an induction of protein of low-molecular weight similar to the mamalian MT in unfertilized eggs and D-stage larvae of the mussel Mytilus galloprovincialis after exposure to high unrealistic cadmium concentrations $\left(2.75 \mathrm{mg} \mathrm{Cd}^{-1}\right)$ in seawater compared to environmental concentrations even in metal-rich areas. The relationships between metal bioaccumulation and metallothionein concentrations were studied in larvae of Mytilus galloprovincialis (Geffard et al., 2002) and of Crassostrea gigas (Geffard et al., 2003) exposed to contaminated estuarine sediment elutriates. Metallothionein induction in larvae was always strongly correlated with increasing metal contents $(\mathrm{Cd}, \mathrm{Cu}$ and $\mathrm{Zn}$ ) in the cytosolic fraction of samples. This is in agreement with our findings for cadmium (experiments II and III, Table 3) and, to a less extent, for copper (experiment III, Table 2).

The induction of MT in veliger larvae has also been studied in Crassostrea virginica by Ringwood and Brouwer (1995) who observed four constitutive MTs (Zn or ZnCu isoforms) in control embryos and during exposure to Cd, two additional isoforms were produced. MTbound Cd increased in exposed embryos and early larval stages prior to MT induction which may be explained in part as Cd binding to constitutive MTs (Roesijadi et al., 1996, 1997). In experiment II and III (Table 3), MT induction took place after a strong cadmium uptake associated with a high Cd dose $\left(200 \mu \mathrm{g} \mathrm{Cd}^{-1}\right)$ i.e. MT concentrations keep increasing with 
incorporated cadmium whereas for copper a slight increase in MT concentrations that levels off at the highest $\mathrm{Cu}$ concentration (increase and plateau, experiment III) is observed (Table 2). The two metals behave differently, copper stimulates the formation of oxygen radicals and has an oxidative effect whereas cadmium does not undergo redox cycling. The induction of MT is not as good with copper as with cadmium and the Cd-dependent resistance to oxidative stress in mussels was ascribed to MT induction by Viarengo et al. (2000), MT induction playing a rôle against oxidative stress.

Table 3: Cadmium (ng Cd mg protein ${ }^{-1}$ ) and metallothionein ( $\mu$ g MT mg protein ${ }^{-1}$ ) concentrations in Crassostrea gigas larvae. The nominal exposure Cd concentration and the measured Cd concentration in the incubation medium are also given.

\begin{tabular}{|c|c|c|c|c|c|}
\hline Experiment & Exposure & $\begin{array}{c}\mathrm{Cd} \\
\mu \mathrm{g} \mathrm{l}^{-1}\end{array}$ & $\begin{array}{l}\text { Proteins } \\
\mathrm{mg} \mathrm{ml}^{-1}\end{array}$ & $\begin{array}{c}\text { ng Cd } \\
\text { mg prot. }^{-1}\end{array}$ & $\begin{array}{c}\mu \mathrm{g} \text { MT } \\
\text { mg prot. }^{-1}\end{array}$ \\
\hline & Control & $<1$ & 3.80 & 1.34 & 6.12 \\
\hline \multirow{2}{*}{$\begin{array}{l}\text { Exp. I } \\
\text { Beginning of } \\
\text { March }\end{array}$} & 25 & 20 & 3.82 & 13.27 & 2.72 \\
\hline & 100 & 84.6 & 2.63 & 27.83 & 0.82 \\
\hline \multirow{3}{*}{$\begin{array}{l}\text { Exp. II } \\
\text { End of } \\
\text { March }\end{array}$} & Control & $<1$ & 14.37 & 0.10 & 4.75 \\
\hline & 50 & 43.3 & 13.15 & 107.90 & 5.71 \\
\hline & 200 & 193 & 9.73 & 176.53 & 10.46 \\
\hline \multirow{3}{*}{$\begin{array}{c}\text { Exp. III } \\
\text { End of April }\end{array}$} & Control & $<1$ & 8.58 & 0.87 & 4.60 \\
\hline & 100 & 92.4 & 7.075 & 251.65 & 5.30 \\
\hline & 200 & 194.4 & 5.23 & 334.32 & 11.70 \\
\hline
\end{tabular}

\section{Effect of the origin of larvae}

Hahn (1998) defined the adaptation process as a series of modifications enhancing the ability of an organism to survive and reproduce in a particular environment. Several mechanisms including biochemical, physiological and behavioural are involved in this process. Millward and Grant (2000) even proposed the pollution-induced community tolerance (PICT) index as indicator of the deleterious effects caused by pollutants on natural communities. The hypothesis, suggested in this paper regarding the origin of larvae, was that adult oysters from Bidassoa have been living all their life in a contaminated estuary and that their offspring was therefore able to stand the toxic effects of copper. Sediments of Bidassoa present a very high metal content $\left(1 \mu \mathrm{g} \mathrm{Cd} \mathrm{g}{ }^{-1}, 77 \mu \mathrm{g} \mathrm{Cu} \mathrm{g}{ }^{-1}\right.$ and $307 \mu \mathrm{g} \mathrm{Zn} \mathrm{g}$, Geffard, 2001), the copper content exceeds the first French level (Cd : 1.2 ; Cu : $45 ; \mathrm{Zn}: 276 \mu \mathrm{g} \mathrm{g}^{-1}$ ) for dumping dredged harbour sediments (Alzieu and Quiniou, 2001). On the contrary, the Arcachon Basin is devoted to oyster farming based on Japanese oysters Crassostrea gigas and is thus assumed to have a good environmental quality (His et al., 1999). Sediments from the Bay of Arcachon present low metal concentrations $\left(0.2 \mu \mathrm{g} \mathrm{Cd} \mathrm{g}^{-1}, 33 \mu \mathrm{g} \mathrm{Cu} \mathrm{g}{ }^{-1}\right.$ and $180 \mu \mathrm{g}$ $\mathrm{Zn}^{-1}$, unpublished data), The results of the first experiment show a toxic effect of copper 
which decreases the MT concentration in larvae from Arcachon oysters. Copper may interfere with MT synthesis (George and Olsson, 1994, Roméo et al., 1997) or Cu bound to MT can form an insoluble $\mathrm{Cu}-\mathrm{MT}$ complex that would precipitate into lysosomes and aid to $\mathrm{Cu}$ elimination under this form (Viarengo et al., 1988).

Another hypothesis could be suggested in relation with the general stress induced by the exceptionnally high temperature experienced during summer 2003. The residence time of water masses in the Arcachon Basin is relatively high and waters could have maintained their temperature constant whereas the estuarine waters of the Bidassoa river receives colder fresh waters from the Pyrenees. This could explain that larvae from Bidassoa oysters do not seem to be affected by copper toxicity in addition to the copper tolerance demonstrated by the toxicity tests (Fig. 2 a and b).

In the second experiment, differences between the origin of larvae are less significant. The increase of MT, observed at $0.25 \mu \mathrm{g} \mathrm{Cu} \mathrm{l}^{-1}$ in larvae from Arcachon oysters occurs at $0.5 \mu \mathrm{g}$ $\mathrm{Cu} \mathrm{l}^{-1}$ in those from Bidassoa, is followed by a decrease. The accumulation of copper by the larvae as a function of copper concentration in the medium tends to be similar to that of MTs concentrations. The results ( $\mathrm{Cu}$ accumulation and MT concentrations) reported in Table 4 may be compared with Experiments I and II displayed in Table 2. There is generally low copper uptake and low MT induction in the larvae. The decrease of copper uptake at $1 \mu \mathrm{g} \mathrm{Cu}$ $\mathrm{l}^{-1}$ in both larvae (Table 4) shows an elimination of the metal which may be due to the formation of Cu-MT insoluble complex described by Viarengo et al. (1988) Larvae from wild oysters.

Table 4. Experiment of July 2004 : Protein, TBARS, Cu and MT concentrations and catalase activity in larvae from different origin Arcachon (ARC) and Bidassoa (BID) and treated with increasing $\mathrm{Cu}$ concentrations (expressed as $\mu \mathrm{g} \mathrm{I}^{-1}$ ). Standard deviations are shown in parenthesis.

\begin{tabular}{|c|c|c|c|c|c|c|c|}
\hline & $\begin{array}{l}\text { Proteins } \\
\mathrm{mg} \mathrm{ml}^{-1}\end{array}$ & $\begin{array}{c}\text { TBARS } \\
\text { nmol } \\
\text { mg prot. }^{-1}\end{array}$ & $\begin{array}{c}\text { CAT } \\
\mu \text { mol min }^{-1} \\
\text { mg prot. }^{-1}\end{array}$ & $\begin{array}{c}\text { Cu } \\
\text { ng } \\
\text { mg prot. }^{1}\end{array}$ & $\begin{array}{c}\mathrm{Cu} \\
\mathrm{ng} \mathrm{g}^{-1}\end{array}$ & $\begin{array}{c}\text { MT } \\
\mu g \\
\text { mg prot. }^{-1}\end{array}$ & $\begin{array}{c}\mathrm{MT} \\
\mu \mathrm{g} \mathrm{g}^{-1}\end{array}$ \\
\hline ARC 0 & $\begin{array}{c}8.57 \\
(0.36)\end{array}$ & $\begin{array}{c}0.54 \\
(0.05)\end{array}$ & $\begin{array}{c}6.66 \\
(0.74)\end{array}$ & $\begin{array}{l}21.93 \\
(3.35)\end{array}$ & $\begin{array}{l}568 \\
(41)\end{array}$ & 3.86 & 104.3 \\
\hline $\mathrm{ARC}+0.25$ & $\begin{array}{c}9.50 \\
(0.67)\end{array}$ & $\begin{array}{c}0.48 \\
(0.06)\end{array}$ & $\begin{array}{l}3.82 * \\
(0.76)\end{array}$ & $\begin{array}{l}22.49 \\
(9.08)\end{array}$ & $\begin{array}{c}613 \\
(148)\end{array}$ & 5.72 & 171.6 \\
\hline $\mathrm{ARC}+0.5$ & $\begin{array}{c}8.84 \\
(0.51) \\
\end{array}$ & $\begin{array}{c}0.53 \\
(0.04) \\
\end{array}$ & $\begin{array}{l}4.78^{*} \\
(0.74) \\
\end{array}$ & $\begin{array}{l}24.23 \\
(5.53) \\
\end{array}$ & $\begin{array}{c}629 \\
(118) \\
\end{array}$ & 5.101 & 138.4 \\
\hline $\mathrm{ARC}+1$ & $\begin{array}{c}9.37 \\
(0.58)\end{array}$ & $\begin{array}{c}0.50 \\
(0.02)\end{array}$ & $\begin{array}{l}4.41^{*} \\
(0.60)\end{array}$ & 16.47 & 437 & 4.878 & 141.0 \\
\hline BID 0 & $\begin{array}{c}6.60 \\
(0.60)\end{array}$ & $\begin{array}{c}0.46 \\
(0.06)\end{array}$ & $\begin{array}{c}9.41 \\
(1.07)\end{array}$ & $\begin{array}{l}25.73 \\
(1.07)\end{array}$ & $\begin{array}{l}506 \\
(31)\end{array}$ & 5.425 & 113.4 \\
\hline $\mathrm{BID}+0.25$ & $\begin{array}{c}6.74 \\
(0.81)\end{array}$ & $\begin{array}{c}0.40 \\
(0.04)\end{array}$ & $\begin{array}{c}9.59 \\
(0.60)\end{array}$ & $\begin{array}{l}22.71 \\
(1.42)\end{array}$ & $\begin{array}{l}459 \\
(41)\end{array}$ & 6.464 & 136.3 \\
\hline $\mathrm{BID}+0.5$ & $\begin{array}{c}7.48 \\
(0.50)\end{array}$ & $\begin{array}{c}0.41 \\
(0.03)\end{array}$ & $\begin{array}{c}8.33 \\
(1.33)\end{array}$ & $\begin{array}{l}26.22 \\
(8.58)\end{array}$ & $\begin{array}{c}587 \\
(116)\end{array}$ & 5.383 & 180.1 \\
\hline $\mathrm{BID}+1$ & $\begin{array}{c}6.45 \\
(1.81)\end{array}$ & $\begin{array}{c}0.49 \\
(0.10)\end{array}$ & $\begin{array}{l}7.41^{*} \\
(1.69)\end{array}$ & 18.1 & 384 & 5.880 & 129.3 \\
\hline
\end{tabular}

*Tuckey’s test of comparison with the corresponding controls significant at $\mathrm{p}<0.05$ 
Data from Table 4 also show that, in the larvae from Arcachon, catalase activity is inhibited in copper-treated samples from $0.25 \mathrm{~g} \mathrm{Cu} \mathrm{l}^{-1}$ which demonstrates the toxic effect of the metal on the enzyme itself. In the same samples, MT concentration is increased and allows the protection against lipid peroxidation since TBARS concentrations do not change in exposed larvae compared to controls. In the case of larvae from Bidassoa oysters (Table 4), catalase is decreased at the highest copper exposure. Larvae from Bidassoa seem to have an "environmental history" which allows some protection against copper toxicity.

Geffard et al. (2003) hypothesized that MT induction in oyster larvae provided an enhanced early-warning tool for evaluating environmental contamination by metals. The measurement of other biomarkers associated with MT determinations may allow an improved approach of contamination. Lagadic et al. (1997) underlined the interest in measuring several biomarkers at the same time in the same animals, which allows a relevant approach to evaluate the effects of pollutants on individuals.

As conclusion, this work demonstrates that oyster larvae may be used to evaluate MTs as biomarkers of metal exposure, since in many cases, metal content and MT concentrations are associated. The advantage in using oyster larvae is the rapid response within $24 \mathrm{~h}$. Nevertheless, the physiological status of parents giving rise to larvae is important. MT induction occurs when the sexual maturity of parents is maximal whereas the induction is not significant when the sexual maturity period is not reached. Moreover, when adults have lived in a polluted area, their larvae may be less sensitive to pollution.

Acknowlegdments; This work was funded by the French Ministry of Environment (program PNETOX 2001 D4E -SRP). We also acknowledge Xavier Caisey for his technical assistance. 


\section{References}

Alzieu, C, Quiniou, F., 2001. Géodrisk - La démarche d'analyse des risques liés à l'immersion des boues de dragage des ports maritimes, in CD-ROM Geodrisk « Logiciel d'évaluation des risques liés à l'immersion des déblais de dragages des ports maritimes », Coord. C. Alzieu , Ed. Ifremer, Juin 2001

Amiard-Triquet, C., Rainglet, F., Larroux, C., Regoli, F., Hummel, H., 1998. Metallothioneins in Arctic bivalves. Ecotoxicology and Environmental Safety 41, 96-102.

Beiras, R., His, E., 1995. Effects of dissolved mercury on embryogenesis, survival and growth of Mytilus galloprovincialis mussel larvae. Marine Ecology Progress Series 126, 185-189.

Boutet, I., Tanguy, A., Riso, R., Auffret, M., Moraga, D., 2002. Immuno-chemical quantification of metallothioneins in the pacific oyster Crassostrea gigas: characterisation of a metal exposure bioindicator. Environmental Toxicology and Chemistry 21, 1009-1014.

Boutet, I., Tanguy, A., Moraga, D., 2003. Organization and nucleotide sequence of the European flat oyster Ostrea edulis heat shock cognate 70 (hsc 70) and heat shock protein (hsp 70) genes. Aquatic Toxicology 65, 221-225.

Bradford, M., 1976. A rapid and sensitive method for the quantification of microgram quantities of protein utilizing the principle of protein-dye blinding. Analytical Biochemistry 72, 248-254.

Bragigand, V., Berthet, B., Amiard, J.C., Rainbow, P.S., 2004. Estimates of trace metal bioavailability to humans ingesting contaminated oysters. Food and Chemical Toxicology 42, 1893-1902.

Bridckà, A., 1933. Polarographic studies with the dropping mercury method. A new test for proteins in the presence of cobalt salts in ammoniacal solution of ammonium chloride. Collection of Czechoslovak Chemical Communications 5, 112-128.

Calabrese, A., MacInnes, J.R., Nelson, D.A., Miller, J.E., 1977. Survival and growth of bivalve larvae under heavy-metal stress. Marine Biology 41, 179-184.

Cossa, D., Lassus, P., 1989. Le cadmium en milieu marin. Biogéochimie et écotoxicologie. Rapports scientifiques et techniques de l'IFREMER, No 16. IFREMER, Brest, France.

Cosson, R.P., 2000. Bivalve metallothioneins as a biomarker of aquatic ecosystem pollution by trace metals : limits and perspectives. Cellular and Molecular Biology (Oxford) 46, 295-309.

Cossu, A., Doyotte, A., Jacquin M.C., Vasseur P., 1997, Biomarqueurs du stress oxydant chez les animaux aquatiques, in : Lagadic, L., Caquet, T., Amiard, J.C., Ramade, F. (Eds), Biomarqueurs en écotoxicologie. Aspects fondamentaux. Masson, Paris, pp. 149-163.

Damiens, G., His, E., Gnassia-Barelli, M., Quiniou, F., Roméo, M., 2004. Evaluation of biomarkers in oyster larvae in natural and polluted conditions. Comparative Biochemistry and Physiology 138C, 121-128.

De Kock, W.C., Kramer, K.J.M., 1994. Active biomonitoring (ABM) by translocation of bivalve molluscs, in: Kramer, K.J.M. (Ed), Biomonitoring of coastal waters and estuaries. CRC Press, Boca Raton, FL., pp. 51-84.

Engel, D.W., Brouwer, M., 1989. Metallothionein and metallothionein-like proteins: physiological importance. Advances in Comparative and Environmental Physiology 5, 5375.

Geffard, A., 2001. Réponses du biota à la contamination polymétallique d'un milieu estuarien, la Gironde, Fr: exposition, imprégnation, induction d'une protéine de détoxication, la métallothionéine, impact au niveau individuel et populationnel, Thèse de Doctorat, Université de Nantes. 
Geffard, A., Geffard, O., His, E., Amiard, J.C., 2002. Relationships between metal bioaccumulation and metallothionein levels in larvae of Mytilus galloprovincialis exposed to contaminated estuarine sediment elutriate. Marine Ecology Progress Series 233, 131142.

Geffard, O., Geffard, A., His, E., Budzinski, H., 2003. Assessment of the bioavailability and toxicity of sediment-associated polycyclic aromatic hydrocarbons and heavy metals applied to Crassostrea gigas embryos and larvae. Marine Pollution Bulletin 46, 481-490.

George, S. G., Olsson, P. E., 1994. Metallothioneins as indicators of trace metal pollution, in: Kramer, K.J.M. (Ed.), Biomonitoring of Coastal Waters and Estuaries. CRC Press, Boca Raton, FL., pp. 151-171.

Hahn, M.E., 1998. Mechanism of innate and acquired resistance to dioxin-like products. Reviews in Toxicology 2, 395-443.

Hamer, D.H., 1986. Metallothionein. Annual Review of Biochemistry 55, 913-951.

His, E., Seaman, M.N.L., Beiras, R., 1997. A simplification of the bivalve embryogenesis and larval development bioassay method for water quality assessment. Water Research 31, 351-355.

His, E., Beiras, R., Seaman, M., 1999. The assessment of aquatic contamination : bioassays with bivalve larvae. Advances in Marine Biology 37, 1-178.

Lagadic, L., Caquet, T., Amiard, J.C., 1997. Intérêt d’une approche multiparamétrique pour le suivi de la qualité de l'environnement, in: Lagadic, L., Caquet, T., Amiard, J.C., Ramade, F. (Eds.), Biomarqueurs en écotoxicologie. Aspects Fondamentaux. Masson, Paris, pp. 393-401.

Langston, W.J., Bebianno, M.J., Burt, G.R., 1998. Metal handling strategies in molluscs, in: Batley, G.E., Langston W.J., Bebianno M.J. (Eds), Metal metabolism in aquatic environments. Chapman and Hall, London, pp. 219-283.

Martin, M., Osborn, K.E., Billig, P., Glickstein, N., 1981. Toxicities of ten metals to Crassostrea gigas and Mytilus edulis embryos and Cancer magister larvae. Marine Pollution Bulletin 12, 305-308.

Millward, R.N., Grant, A., 2000. Pollution-induced tolerance to copper of nematode communities in the severely contaminated Restronguet Creek and adjacent estuaries, Cornwall, United Kingdom. Environmental Toxicology and Chemistry 19, 454-461.

Mouneyrac, C., Amiard, J.C., Amiard-Triquet, C., 1998. Effects of natural factors (salinity and body weight) on cadmium, copper, zinc and metallothionein-like protein levels in resident populations of oysters (Crassostrea gigas) from a polluted estuary. Marine Ecology Progress Series 162, 125-135.

Pavičić, J.,1981. Interaction of $\mathrm{Cd}$ and $\mathrm{Zn}$ in relation to oxygen consumption in early stages of marine bivalve molluscs. Vèmes Journées Etudes des Pollutions, Commission Internationale pour l’Exploitation Scientifique de la Mer Méditerranée, Cagliari, pp. 627633.

Pavičić, J., Skreblin, M., Kregar, I., Tusek-Znidaric, M., Stegnar, P., 1985. Heavy metal tolerance of the developing veliger of Mytilus galloprovincialis in relation to induced synthesis of metal-binding proteins. 5th International conference. Heavy Metals in the Environment, Athens, September 10-13.

Pavičić, J., Skreblin, M., Kregar, I., Tusek-Znidaric, M., Stegnar, P., 1994. Embryo-larval tolerance of Mytilus galloprovincialis. exposed to the elevated sea water metal concentrations- I. Toxic effects of $\mathrm{Cd}$. $\mathrm{Zn}$ and $\mathrm{Hg}$ in relation to the metallothionein level. Comparative Biochemistry and Physiology 107C, 249-257.

Quiniou, F., Damiens, G., His, E., Caisey, X., Tanguy, A., Gnassia-Barelli, M., Roméo, M., 2004. Développement des biomarqueurs enzymatiques et protéiques chez les larves d'huître, pour l'évaluation précoce de stress environnementaux. Colloque de mise en 
place du réseau Atlantique sur les biomarqueurs de santé chez les bivalves: Applications écotoxicologiques et en mariculture. Congrès ACFAS 2004 (Association Francophone pour le Savoir), Montréal, May 12th, 2004.

Quiniou, F., His, E., Delesmont, R., Caisey, X. 2005. Bio-indicateur de la toxicité potentielle de milieux aqueux : bio-essai “développement embryo-larvaire de bivalve”. Éd. Ifremer, Méthodes d'analyse en milieu marin, 22p

Ringwood, A.H., Brouwer, M., 1995. Patterns of metalloprotein expression in oyster embryos. Marine Environmental Research 39, 101-105.

Robert, R., His, E., 1985. Combined effects of salinity and cadmium chloride upon embryos and larvae of the Japanese oyster Crassostrea gigas. Marine Environmental Research 15, 303-312.

Roesijadi, G., 1992. Metallothioneins in metal regulation and toxicity in aquatic animals. Aquatic Toxicology 22, 81-114.

Roesijadi, G., Hansen, K.M., Fuentes, M.E., 1995. Cadmium induced expression of metallothionein and suppression of RNA to DNA ratios during molluscan development. Toxicology and Applied Pharmacology 133, 130-138.

Roesijadi, G., Hansen, K.M., Unger, M.E., 1996. Cadmium-induced metallothionein expression during embryonic and early larval development of the Mollusc Crassostrea virginica. Toxicology and Applied Pharmacology 140, 356-363.

Roesijadi, G., Hansen, K.M., Unger, M.E., 1997. Metallothionein mRNA accumulation in early developmental stages of Crassostrea virginica following pre-exposure and chalenge with cadmium. Aquatic Toxicology 39,185-194.

Roméo, M., Cosson, R.P., Gnassia-Barelli, M., Risso, C., Stien, X., Lafaurie, M., 1997. Metallothionein determination in the liver of the Sea Bass Dicentrarchus labrax treated with copper and B(a)P. Marine Environmental Research 44, 275-284.

Schiff, K., Diehl, D., Valkirs, A., 2004. Copper emissions from antifouling paint on recreational vessels. Marine Pollution Bulletin 48, 371-377.

Stebbing, A., Akesson, B., Calabrese, A., Gentile, J.H., Jensen, A., Lloyd, R., 1980. The role of bioassays in marine pollution monitoring, Rapports et Procès-Verbaux des réunions, Conseil International pour l’Exploration Scientifique de la Mer 179, 322-332.

Thompson, J.A.J., Cosson R.P., 1984. An improved electrochemical method for the Quantification of Metallothionein in marine organisms. Marine Environmental Research 11, 137-152.

Viarengo, A., Moore, M.N., Mancinelli, G., Mazzucotelli, A., Pipe, R.K., Farrar, S.V., 1987. Metallothioneins and lysosomes in metal toxicity and accumulation in marine mussels: the effect of cadmium in the presence and absence of phenanthrene. Marine Biology 94, 251257.

Viarengo A., Canesi L., Pertica M., Mancinelli G., Orunesu M., 1988. Biochemical characterization of a copper-thionein involved in $\mathrm{Cu}$ accumulation in the lysosomes of the digestive gland of mussels exposed to the metal. Marine Environmental Research, 24, 163-166Viarengo, A., Ponzano, E., Dondero, F., Fabbri, R., 1997. A simple spectrophotometric method for metallothionein evaluation in marine organisms : an application to Mediterranean and Antarctic molluscs. Marine Environmental Research 44, 69-84.

Viarengo, A., Burlando, B., Cavaletto, M., Marchi, B., Ponzano, E., Blasco, J., 2000. Role of metallothionein against oxidative stress in the mussel Mytilus galloprovincialis. American Journal of Physiology - Regulatory, Integrative and Comparative Physiology 277,R1612R1619. 